logos_i_ethos_2016_2_(42), s. 75-101

DOI: http://dx.doi.org/10.15633/lie.1915

ks. Marek Sołtysiak

Uniwersytet Papieski Jana Pawła II w Krakowie

\title{
Alegoria w tradycji hermeneutycznej. Gadamerowska rehabilitacja alegorii
}

Poznanie ściśle naukowe, związane z określonymi metodami, nie wyczerpuje całokształtu ludzkiego poznania. Hermeneutyka filozoficzna, oprócz powyższego poznania, podkreśla znaczenie poznania w naukach humanistycznych, jak również Marek Sołtysiak - kapłan, doktor filozofii, adiunkt Katedry Filozofii Poznania Wydziału Filozoficznego UPJPII. Zajmuje się filozofią poznania i antropologią filozoficzną. Zainteresowania naukowe: filozofia niemiecka XX wieku (w szczegolności M. Heidegger i H. G. Gadamer) oraz myśl filozoficzna R. Descartesa. rozumienia potocznego, jako szczególnych dróg prowadzących do prawdy. Bogactwo treści występujących w każdym z tych poznań wymaga zastosowania odpowiednich narzędzi poznawczych. Dla tradycji hermeneutycznej takimi narzędziami poznawczymi umożliwiającymi rozumienie określonych rzeczy są zagadka i metafora, a przede wszystkim alegoria i symbol ${ }^{1}$. W niniejszym artykule spróbujemy bliżej przyjrzeć się znaczeniu alegorii w tradycji hermeneutycznej. Jeżeli chodzi o jej znaczenie w starożytności, to problematykę tę porusza Mikołaj Domaradzki w pracy Filozofia antyczna wobec problemu interpretacji. Rozwój alegorezy od przedsokratyków do Arystotelesa ${ }^{2}$. Celem niniejszego artykułu jest wskazanie na najważniejsze etapy zastosowania alegorii w poznaniu: od stoików, przez ojców Kościoła, do jej zakwestionowania w czasach reformacji i oświecenia, a w szczególności

1 Por. M. Domaradzki, Filozofia antyczna wobec problemu interpretacji. Rozwój alegorezy od przedsokratyków do Arystotelesa, Poznań 2013, s. 67. Na temat znaczenia symbolu w hermeneutyce filozoficznej patrz także: M. Sołtysiak, Symbol hermeneutyczny a symboliczność dzieła sztuki według Hansa-Georga Gadamera, „Logos i Ethos” 2014 nr 2 (37), s. 21-46.

2 Por. M. Domaradzki, Filozofia antyczna wobec problemu interpretacji..., dz. cyt. 
w filozofii Immanuela Kanta. Ukażemy także konsekwencje jej odrzucenia w estetyce. W dalszej części artykułu spróbujemy wskazać cele, jakie przyświecały Hansowi-Georgowi Gadamerowi w jej rehabilitacji.

\section{Hermeneutyczny aspekt alegorii}

„Alegoria” (gr. allēgoría) pochodzi od greckich słów: allos - „inny” i agoreuo - „przemawiać publicznie”, „mówić coś innego” ${ }^{3}$. Pojęcie „alegoria”, pierwotnie związane z retoryką, zostało utworzone stosunkowo późno przez gramatyka Pseudo-Heraklaitosa w I wieku p.n.Chr. . Mamy w nim do czynienia z ustanowionym zewnętrznym, konwencjonalnym stosunkiem pomiędzy znaczeniem dosłownym a znaczeniem przenośnym, dzięki czemu następuje przekład pierwszego znaczenia na drugie. Według Giovanniego Realego „Filozofia grecka zawsze posługiwała się alegorią, ale szczególnie pod koniec ery pogańskiej i w pierwszych wiekach ery chrześcijańskiej, kiedy to interpretacja alegoryczna stała się prawdziwą metodą filozoficznego wyjaśniania" ${ }^{5}$. Także według Gadamera „Jądrem antycznej hermeneutyki jest problem interpretacji alegorycznej”" . Domaradzki podkreśla, że „Alegoria mieści się na pograniczu dwóch odmiennych tradycji. Z jednej bowiem strony alegoria jest techniką komponowania («zaszyfrowywania») odnośnego «komunikatu» (utworu poetyckiego, przepowiedni, wyroczni), a z drugiej - techniką jego interpretowania («odszyfrowania»)”7. Kiedy mówimy o alegorii

3 Por. X. Léon-Dufour SJ, Słownik Nowego Testamentu, tłum. bp K. Romaniuk, Poznań 1986, s. 587-588. Por. E. Sarnowska-Temeriusz, Alegoria, [w:] Stownik literatury staropolskiej, red. T. Michałowska, Wrocław-Warszawa-Kraków 1998, s. 20-26.

4 Por. J. Grondin, Wprowadzenie do hermeneutyki filozoficznej, tłum. L. Łysień, Kraków 2007, s. 37. Obszernie na ten temat pisze M. Domaradzki, Filozofia antyczna wobec problemu interpretacji..., dz. cyt., s. 29.

5 G. Reale, Historia filozofii starożytnej, tłum. E. I. Zieliński, t. 5, Lublin 2002, s. 21.

6 H.-G. Gadamer, Klassische und philosophische Hermeneutik, [w:] H.-G. Gadamer, Gesammelte Werke 2. Hermeneutik II, Tübingen 1993, s. 94. W filozofii Platona spotykamy termin hiponoia, który oznacza formę pośredniego przekazu polegającą na tym, że co innego się mówi, aby coś innego dać do zrozumienia. Czyli poza sensem jawnym przekazywano ukryty sens głębszy.

M. Domaradzki, Filozofia antyczna wobec problemu interpretacji..., dz. cyt., s. 19. 
jako technice zaszyfrowywania pewnych treści, oznacza to, że wiążemy ją $z$ tradycją retoryczną i traktujemy jako problem stylistyczny ${ }^{8}$. Natomiast kiedy rozpatrujemy problem odszyfrowywania danego komunikatu, oznacza to, że przypisujemy alegorię do tradycji hermeneutycznej i rozumiemy jako narzędzie interpretacji. To dzięki jej zastosowaniu możemy wydobyć ukrytą prawdę tekstu. Jednakże „Starożytność zasadniczo nie odróżnia techniki komponowania («zaszyfrowania») odnośnego «komunikatu» (utworu poetyckiego, przepowiedni, wyroczni, itd.) od techniki jego interpretowania [...] dwuznaczność ta zaznacza się już na poziomie uzusu językowego: grecki czasownik alegoryzować (à $\lambda \lambda \eta \gamma o \rho \varepsilon i v)$ znaczy zarówno «wyrażać się alegorycznie», jak i «interpretować alegorycznie»" Aby zachować jednolitość terminologii, Domaradzki proponuje w swojej pracy używać pojęcia alegorii w rozumieniu kompozycji utworu, natomiast pojęcia alegorezy wyłącznie w odniesieniu do jego hermeneutycznej interpretacji ${ }^{10}$. My również przyjmujemy to rozróżnienie w naszych rozważaniach.

W związku z powyższym rozgraniczeniem pomiędzy retorycznym a hermeneutycznym aspektem alegorii dokonanym przez Domaradzkiego nasuwają się dwie uwagi. Po pierwsze: alegoria jako figura retoryczna niejako domaga się alegorezy ${ }^{11}$, czyli użycia sensie hermeneutycznym, po-

8 „[...] alegoria nie oznacza tylko figury retorycznej i sensu interpretacyjnego (sensus allegoricus), lecz także odpowiednie obrazowe przedstawienie pojęć w sztuce" (H.-G. Gadamer, Prawda i metoda. Zarys hermeneutyki filozoficznej, tłum. B. Baran, Kraków 2004, s. 121).

9 M. Domaradzki, Filozofia antyczna wobec problemu interpretacji..., dz. cyt., s. 24.

10 „Pojęcia alegorii używać będę wyłącznie w odniesieniu do specyficznej techniki literackiej, której efektem jest stworzenie (kompozycja) określonego utworu. Natomiast pojęciem alegorezy posługiwać się będę wyłącznie w odniesieniu do hermeneutycznej czynności interpretowania danego dzieła, skutkującej przypisaniem mu określonego sensu" (M. Domaradzki, Filozofia antyczna wobec problemu interpretacji..., dz. cyt., s. 25).

${ }_{11}$ Alegorezy nie należy mylić z egzegezą. Egzegeza jest objaśnianiem literalnego sensu tekstu. Alegoreza zaś jest ukazaniem jego ukrytego sensu, prawdy w nim zawartej. Zastosowanie alegorezy wiąże się pewne niebezpieczeństwo, ponieważ można uznać, że wszystkie przekazy zawierają ukryty sens. Pomimo tego, że granice pomiędzy nimi są płynne, trzeba uznać, że egzegeza pozostaje „w obrębie” objaśniającego tekstu, natomiast alegoreza wychodzi „poza ów tekst”. „Czytanie” należy odnieść do egzegezy, natomiast interpretację do alegorezy. Por. M. Domaradzki, Filozofia antyczna wobec problemu interpretacj..., dz. cyt., s. 26. 
nieważ kiedy tekst zostaje celowo zaszyfrowany, to zrozumienie zawartej w nim prawdy wymaga odszyfrowania odnośnej treści. A zatem w takim przypadku hermeneutyka jest niejako drugą, naturalną stroną retoryki.

Po drugie: zaszyfrowana treść przekazu niekoniecznie musi być wcześniejszym, celowym zabiegiem retorycznym, ale może wynikać z samej istoty przedstawianej rzeczy. Niekiedy znajdujemy się w takiej sytuacji rozumienia, że określona rzecz nie jawi nam się bezpośrednio, ale tylko może być nam dostępna za pośrednictwem alegorii. Naszym zadaniem jest rozszyfrowanie przekazywanych treści i dotarcie do prawdy. Jest to zatem problem hermeneutyczny, pozbawiony poprzedzającego go zabiegu retorycznego polegającego na celowym ukryciu treści. Takim przykładem może być interpretacja snu.

Potrzebę zastosowania alegorii do interpretacji mitów dostrzegli stoicy, ponieważ świat starożytnej Grecji przedstawiony w mitach stawał się coraz mniej zrozumiały. Dla zachowania jego spójności należało ratować związaną z nim tradycję i dokonać reinterpretacji mitów. Aby to osiągnąć, stoicy zastosowali hermeneutyczną metodę interpretacji mitów, czyli alegorezę $^{12}$. W związku z jej zastosowaniem groziło jednak niebezpieczeństwo arbitralnego rozumienia przekazu. Aby nie doszło do takich nadużyć w interpretacji, stoicy zalecali najpierw zrozumienie literalnego tekstu, przy uwzględnieniu etymologii, a w następnej kolejności dopuszczali możliwość interpretacji hermeneutycznej. Alegoreza stała się dwustopniową metodą interpretacji przekazów słownych i ikonograficznych. Pierwszy jej etap polega na zrozumieniu dosłownym - literalnym przekazu. W drugim etapie należy wydobyć znaczenie ukryte pod znaczeniem bezpośrednim. Samo literalne odczytanie mitów ukazywało niewłaściwe zachowanie się bogów, toteż jako takie nie mogło być wzorem dla ludzi ${ }^{13}$.

12 Por. J. Grondin, Wprowadzenie do hermeneutyki filozoficznej, dz. cyt., s. 37. Szczególne zastosowanie alegoreza ma $\mathrm{w}$ rozumieniu tekstu biblijnego, jest to „[...] metoda hermeneutyczna polegająca na odkrywaniu w tekście biblijnym poziomu pozaliteralnego, mająca na celu pogłębienie chrześcijańskiego poznania i wiary oraz uobecnienie i aktualizację orędzia biblijnego" (K. Wojciechowska, Alegoryczna interpretacja Biblii, alegoreza, [w:] Religia, red. T. Gadacz, B. Milerski, t. 1, Warszawa 2001, s. 139).

13 Bogowie byli grubiańscy, mściwi, zazdrośni, często oszukiwali ludzi. 
Stoicy oczyścili mity ze skandalicznych zachowań bogów przez odkrycie w nich głębszego, prawdziwego znaczenia. W związku $\mathrm{z}$ taką ich interpretacją pojawia się pytanie: czy stoicy odkryli głębszy sens mitów, czy też narzucili im nowe znaczenie? Jean Grondin i Hans-Georg Gadamer skłaniają się ku pierwszej wersji odpowiedzi, tzn. że stoicy zastosowawszy alegorezę, odkryli głębszy sens mitów. Wbrew temu, co twierdzą wyżej wymienieni filozofowie, wydaje się jednak, że stoicy nadali mitom nowe znaczenie. Dlatego w interpretacji mitów dokonanej przez stoików mamy do czynienia $\mathrm{z}$ retorycznym, a nie $\mathrm{z}$ hermeneutycznym aspektem alegorii. Należy zauważyć, że interpretacja hermeneutyczna stała się swoistym kluczem interpretacji, który w przypadku mitów, został im przypisany przez stoików, przez co stał się on czymś utrwalonym i kanonicznym. Cel, jaki stoicy osiągnęli przez reinterpretację mitów, dotyczył zgodności rozumowego pojmowania świata z jego obrazem mitycznym, tzn. wykazali, że nie ma sprzeczności pomiędzy rozumem a mitem ${ }^{14}$. Poza tym osiągnęli oni także cel pragmatyczny - zachowali i utrwalili autorytetu starożytnych poetów.

Następny etap w rozwoju hermeneutycznej interpretacji alegorii przypada na początku naszej ery, a związany jest z pojawieniem się i rozwojem chrześcijaństwa ${ }^{15}$. Grondin zauważa, że „W ówczesnej epoce (od szkoły stoickiej do patrystyki) powszechne było przekonanie, że wszystko, co religijne, obraca się wokół symbolu, tajemnicy, niejasności. To, co religijne, traktuje o duchu, czyli o czymś ezoterycznym, czego duchowy czy pneumatyczny sens odsłania alegoria"16. W związku z rozumieniem Biblii pojawił się problem: kiedy w interpretacji należy zastosować alegorezę? Odpowiedź na to pytanie była o tyle ważna, że mogła uchronić Biblię od arbitralnych i w konsekwencji od fałszywym interpretacji. Rozwiązania

14 Por. H.-G. Gadamer, Mythos und Logos, [w:] H.-G. Gadamer, Gesammelte Werke 8. Ästhetik und Poetik I, Tübingen 1993, s. 170-173.

15 Alegorię wykorzystywali również Żydzi we wczesno rabinistycznej interpretacji Biblii. Sięgali po nią także pieśniarze wędrowni, aby dostosować się do poziomu intelektualnego audytorium.

16 J. Grondin, Wprowadzenie do hermeneutyki filozoficznej, dz. cyt., s. 40. 
tego problemu podjął się Filon z Aleksandrii ${ }^{17}$, Żyd żyjący w diasporze w Aleksandrii, uważany za ojca alegorii. W dziele zatytułowanym Legum allegoriae (Alegoria praw) połączył on żydowską teologię z hellenistyczną filozofią. Rozwinął w nim hermeneutyczną interpretację alegorii, czyli alegorezę w sposób systematyczny i uczynił ją filozoficzną metodą dotarcia do prawdy. Wskazał także na jej uniwersalny aspekt w zastosowaniu do Pisma Świętego, ponieważ sama literalna interpretacja nie wystarcza w jego zrozumieniu. Alegorezę należy stosować według Filona wtedy, kiedy dosłowna interpretacja stwarza nieporozumienia. Gdy w treści Pisma Świętego pojawiają się aporie, absurdy i błędy, to są to znaki pozostawione przez Boga dla ludzi, aby te miejsca interpretować alegorycznie. Jednakże nie każdy, według niego, może podjąć się tego zadania. Interpretacji alegorycznej Pisma Świętego może dokonać tylko ten, kto jest odpowiednio przygotowany, tzn. wykształcony i wtajemniczony, ponieważ tylko wtedy ktoś taki jest godny dotrzeć do głębszego sensu przekazu, ukrytego pod brzmieniem dosłownym.

Podobnie jak Filon, uniwersalny aspekt alegorezy w biblistyce podkreślał jeden z wielkich ojców Kościoła zachodniego, św. Augustyn. Także według niego dosłowna lektura Pisma Świętego nie wystarcza w jego zrozumieniu. Wprowadził on rozróżnienie pomiędzy słowem zewnętrznym (dostępnym wszystkim - literalne rozumienie tekstu) a słowem wewnętrznym, w którym wyróżnił słowo serca, dostępne tylko wtajemniczonym, odpowiednio do tego przygotowanym. Zastosowanie hermeneutycznej interpretacji pozwoliło mu przejść od słowa zewnętrznego (logos zewnętrzny) do słowa wewnętrznego (logos wewnętrzny), i w ten sposób zrozumieć ukryty sens przekazu. Aby jednak uniknąć dowolności w rozumieniu Biblii, Augustyn, podobnie jak jego poprzednicy, zalecał rozumienie literalne tekstu. Od egzegety wymagał solidnego przygotowania: opanowania języków, w jakich Pismo Święte zostało spisane, znajomości archeologii, astronomii, geografii, historii, a nawet astrologii ${ }^{18}$.

17 Por. J. Grondin, Wprowadzenie do hermeneutyki filozoficznej, dz. cyt., s. 38.

18 Por. Św. Augustyn, O nauce chrześcijańskiej, tłum. J. Sulowski, Warszawa 1989; Św. Augustyn, O Trójcy świętej, tłum. M. Stokowska, Poznań-Warszawa-Lublin 1963. 
Wybitnymi teoretykami hermeneutycznej metody interpretacji (alegorezy) w czasach ojców Kościoła ${ }^{19}$ byli: Klemens Aleksandryjski i Orygenes. Według pierwszego tekst Pisma Świętego ma podwójny sens: literalny (bezpośredni) i duchowy (ukryty). Ten drugi sens należy interpretować alegorycznie, aby wydobyć ukrytą w nim prawdę. Konieczność interpretacji hermeneutycznej (alegorezy) Pisma Świętego wynikała z samej natury przekazu biblijnego. Natomiast dla Orygenes $\mathrm{a}^{20}$ alegoreza odzwierciedlała się w typologii znaczeń Starego i Nowego Testamentu. Grecki rzeczownik typos znaczy: przekład, wzór, wyobrażenie, treść, ślad czegoś, co ma nadejść. „[...] wszystkie te terminy są zbliżone do pojęcia obrazu (eikon), modelu (typos: 1 Tes. 1, 7); zawierają one jednak najczęściej pewne rysy charakterystyczne, które je zbliżają do typu zapowiedzi" ${ }^{21}$. Według Orygenesa wydarzenia i osoby ze Starego Testamentu są typami wydarzeń i osób Nowego Testamentu ${ }^{22}$.

W biblistyce średniowiecznej, zgodnie z egzegezą patrystyczną, stosowano przede wszystkim interpretację alegoryczną (alegorezę), obok wykładni moralnej i mniej popularnej literalnej (dosłownej). Ważną rolę w upowszechnieniu alegorezy w tym czasie odegrał Jan Kasjan, który rozwinął metodę poczwórnego sensu Pisma Świętego: dosłownego, tropologicznego (moralnego), anagogicznego (eschatologicznego) i alegorycznego ${ }^{23}$.

W średniowieczu obok hermeneutycznego znaczenia alegorii (alegorezy) powrócono do jej sensu retorycznego. Alegoria zaczęła pełnić po-

19 W okresie patrystycznym szczególnie ważną rolę w interpretacji Biblii odegrały szkoły egzegetyczne: szkoła aleksandryjska (por. H. Langkammer, Aleksandryjska szkoła egzegetyczna, [w:] Encyklopedia katolicka, t. 1, Lublin 1985, s. 348) i szkoła antiocheńska (por. H. Langkammer, Antiocheńska szkoła egzegetyczna, [w:] Encyklopedia katolicka, t. 1, Lublin 1985, s. 647). Głównymi przedstawicielami szkoły aleksandryjskiej (II-V w.) byli Orygenes i Klemens Aleksandryjski, natomiast szkoły antiocheńskiej (III-V w.) Lucjan z Samosaty (III-IV w.) i Jan Chryzostom. Przedstawiciele szkoły antiocheńskiej twierdzili, że alegoria i interpretacja symboliczna nie stanowią właściwej metody rozumienia Pisma Świętego.

${ }_{20}$ Por. J. Grondin, Wprowadzenie do hermeneutyki filozoficznej, dz. cyt., s. 41-46.

21 P. Grelot, Typ, [w:] Stownik teologii biblijnej, red. X. Leon-Dufour, tłum. bp K. Romaniuk, Poznań-Warszawa 1985, s. 992.

${ }^{22}$ Tak na przykład Adam jest typem Chrystusa; wyprowadzenie ludu z niewoli egipskiej przez Mojżesza jest typem wyzwolenia z niewoli grzechu przez Chrystusa.

23 Por. H.-G. Gadamer, Klassische und philosophische Hermeneutik, dz. cyt., s. 94. 
dwójną rolę: filozoficzno-teologiczną i estetyczną ${ }^{24}$. Jeśli chodzi o pierwszą funkcję alegorii, to jej zadaniem było wyrażanie ukrytych prawd filozoficznych i teologicznych, które były nieznane większości ludzi. Zrozumienie tych prawd przez ogół było łatwiejsze, gdy zostały ukazane w języku przenośnym niż gdyby były podane dosłownie. Natomiast celem jej zastosowania estetycznego było nie tyle zrozumienie przekazywanych prawd, ile uczynienie ich na tyle atrakcyjnych, aby zainteresować nimi jak największą liczbę odbiorców. Francesco Petrarka i Giovanni Boccaccio używali alegorii w poezji do ukrycia zwyczajnych, powszechnie znanych prawd i dlatego budzących małe zainteresowanie odbiorców. Te same prawdy przedstawione przez nich za pomocą alegorii były trudniejsze do zrozumienia, ale za to ciekawsze. Według Petrarki „Obowiązkiem poety jest wymyślać, to znaczy układać i ozdabiać; prawdę rzeczy znikomych i naturalnych czy jakichkolwiek innych ukazywać w artystycznych barwach i okrywać osłoną uroczej fikcji. Jeśli się ją osłoni, zajaśnieje prawda tym milsza, im trudniejsza była do znalezienia" ${ }^{25}$. Należy zaznaczyć, że użycie fikcji poetyckiej dla zainteresowania odbiorcy, według Petrarki, nie było kłamstwem, ponieważ „[...] nie jest zamierzeniem poetów kogokolwiek wprowadzać w błąd swymi wymysłami”26.

\section{Zakwestionowanie alegorii w rozumieniu Biblii przez reformację}

Gadamer zwraca uwagę, że po raz pierwszy zakwestionowano zastosowanie alegorii w interpretacji Pisma Świętego na początku XVI wieku uczyniła to reformacja ${ }^{27}$. Alegoria, a dokładniej mówiąc alegoreza, jako

24 Por. W. Tatarkiewicz, Historia estetyki. Estetyka nowożytna, t. 3, Warszawa 1991, s. 18.

25 F. Petrarca, Epistolae Seniles, XII, 2, [w:] W. Tatarkiewicz, Historia estetyki. Estetyka nowożytna, t. 3, Warszawa 1991, s. 22.

26 G. Boccaccio, Genealogia Deorum Gentilium, XIV, 13, [w:] W. Tatarkiewicz, Historia estetyki. Estetyka nowożytna, t. 3, dz. cyt., s. 24.

27 Do 1943 roku wśród katolickich badaczy Biblii dominowała alegoroza, kiedy to papież Pius XII nakazał dowartościować literalną interpretację. 30 września 1943 roku papież Pius XII opublikował encyklikę Divino afflante Spiritu (O właściwym rozwoju studiów biblijnych). Podkreślił 
metoda interpretacji Pisma Świętego została odrzucona przez zwolenników reformacji na korzyść interpretacji dosłownej ${ }^{28}$. Interpretacja alegoryczna (alegoreza) była zakorzeniona w tradycji Kościoła rzymskiego, dlatego jej deprecjacja oznaczała odrzucenie autorytetu Urzędu Nauczycielskiego Kościoła w rozumieniu Biblii. Martin Luter ogłosił, że w rozumieniu Słowa Bożego wystarczy sama zasada sola scriptura. Według niej „sacra scriptura sui ipsius interpres”, tj. Pismo Święte samo siebie interpretuje ${ }^{29}$. Jednak indywidualna, samodzielna lektura Pisma Świętego bez odwołania się do nadrzędnego autorytetu Kościoła spowodowała pojawienie się problemu $\mathrm{z}$ arbitralnością rozumienia ${ }^{30}$. Należy zauważyć, że do reformacji, to właśnie rozumienie literalne było pozbawione dowolności, w związku z wymogami, jakie Kościół stawiał czytelnikowi. Tylko wybrane osoby, wcześniej odpowiednio przygotowane, mogły czytać Pismo Święte. Reformacja odrzuciła te ograniczenia w lekturze Pisma Świętego, a z nimi także interpretację hermeneutyczną alegorii ${ }^{31}$. Zarówno retoryczne znaczenie alegorii, jak również jej hermeneutyczna interpretacja w rozumieniu biblijno-teologicznym były w dalszym ciągu stosowane w Kościele katolickim.

Natomiast niezależnie od wyznania, podobnie jak to było w średniowieczu, artyści używali alegorii, aby wzbogacić treść przekazu i uczynić go bardziej interesującym. Szczególne znaczenie alegoria ma w grafikach Albrechta Dürera ${ }^{32}$, w malarstwie Pietera Bruegla ${ }^{33}$, a przede wszystkim

w niej potrzebę znajomości języków oryginalnych Biblii, jak również innych języków starożytnych, dla lepszego zrozumienia natchnionego autora.

${ }_{28}$ Patrz rozwój hermeneutyki protestanckiej, [w:] H.-G. Gadamer, Klassische und philosophische Hermeneutik, dz. cyt., s. 92-117.

29 Por. H.-G. Gadamer, Klassische und philosophische Hermeneutik, dz. cyt., s. 96.

30 Por. H.-G. Gadamer, Klassische und philosophische Hermeneutik, dz. cyt., s. 96-100, oraz por. H.-G. Gadamer, Rhetorik und Hermeneutik, [w:] H.-G. Gadamer, Gesammelte Werke 2. Hermeneutik II, Tübingen 1993, s. 276-291.

31 Również pośród zwolenników humanizmu, między innymi u Erazma z Rotterdamu, na pierwszy plan wysunęła się interpretacja literalna.

32 Zob. A. Dürer, Rycerz, śmierć i diabeł, 1513 r., miedzioryt; Melancholia, 1514 r., miedzioryt.

${ }_{33}$ Zob. P. Bruegel, Walka karnawału z postem, 1559 r., olej na desce; Przysłowia niderlandzkie, 1559 r., olej na desce; Wieża Babel, 1563 r., olej na desce. 
w wizjach i złożonej symbolice dzieł Hieronima Boscha ${ }^{34}$. Odbiorca, który chciał z ich dzieł odczytać ukryte bogactwo treści, musiał zastosować hermeneutyczną interpretację alegorii. Mówiąc dokładniej, musiał znać odpowiedni klucz interpretacyjny umieszczonych w nich alegorii. Dlatego „W XVI i XVII wieku powstawały kodeksy klasyfikujące i opisujące wygląd i atrybuty alegorii (m.in. alegoria Muzyki, Czasu, Sprawiedliwości, Kościoła), niekiedy z towarzyszącą temu ilustracją. Alegoria zyskała popularność w literaturze moralizatorskiej i dydaktycznej, moralitetach, poematach romansowo-moralistycznych, utworach ukazujących idee polityczne i historiozoficzne, przypowieściach i bajkach zwierzęcych"35.

Alegoria była tak często stosowana i tak różne treści były przez nią przekazywane, że stawała się niezrozumiała dla większości ludzi, dlatego też należało nie tylko ujednolicić znaczenie odpowiednich atrybutów, ale też stworzyć odpowiedni ich katalog. Temu zadaniu podołał znakomicie Cesare Ripa w swoim dziele życia, jakim jest Ikonologia ${ }^{36}$ wydana w 1593 roku. Stała się ona najbardziej znanym słownikiem pojęć ikonograficznych. Posługiwali się nią malarze, rzeźbiarze i poeci w następnych stuleciach.

\section{Deprecjacja alegorii w rozumieniu dzieła sztuki w oświeceniu}

Hermeneutyczne znaczenie alegorii od starożytnej Grecji aż po epokę baroku związane było z dogmatyczną interpretacją przekazów. Homer jako pierwszy zastosował ścisłe racjonalistyczne kryteria interpretacji mitów. W czasach patrystycznych rozumienie Pisma Świętego zostało

34 Zob. H. Bosch, Sąd Ostateczny, ok. 1500-1510 r., olej na desce; Piekło, 1500-1510 r., olej na desce; Statek szaleńców, ok. 1490-1500 r., olej na desce; Śmierć skąpca, ok. 1490-1500 r., olej na desce.

35 K. Wojciechowska, Alegoria, [w:] Religia, red. T. Gadacz, B. Milerski, dz. cyt., s. 139. W malarstwie posługiwano się skomplikowaną alegorią przedstawiającą często znikomość życia ludzkiego i chwałę życia wiecznego. Popularne były motywy: tańca śmierci, koła życia i śmierci, sądu ostatecznego i raju.

36 Por. C. Ripa, Ikonologia, tłum. I. Kania, Kraków 1998. 
podporządkowane jedności doktryny chrześcijańskiej. Reformacja podważyła znaczenie alegorii w jego interpretacji. Natomiast ważną rolę odgrywała ona w sztuce i poezji. Ostatnią epoką, w której dowartościowano alegorię w jej hermeneutycznym znaczeniu, był barok.

Schyłek zainteresowania alegorią aż do zakwestionowania stosowania alegorezy w interpretacji dzieła sztuki rozpoczął się w oświeceniu. Gadamer wskazuje na szereg przyczyn, które spowodowały w konsekwencji jej odrzucenie ${ }^{37}$. Przede wszystkim „[...] na pozór oczywiste artystyczne przeciwieństwo między symbolem a alegorią to dopiero wynik filozoficznego rozwoju z ostatnich dwóch stuleci” ${ }^{38}$. Alegorię rozumiano jako przedstawienie dowolne, konwencjonalne, określone racjonalnie, a w następstwie tego, jako małowartościowe dla sztuki. Na zasadzie przeciwieństwa w stosunku do niej dowartościowany został symbol. Estetyka klasycyzmu kontynuowała to dziedzictwo oświecenia, podkreślając absolutne różnice pomiędzy alegorią a symbolem. Podstawą ich przeciwstawienia było utożsamienie symboliczności ${ }^{39} \mathrm{z}$ istotą $\mathrm{i}$ wewnętrznością, a alegorii ze sztucznością i z powierzchniowością tego, co było przedstawiane. Szczególnie jest to widoczne w niemieckiej estetyce czasu Gottholda E. Lessinga i Johanna G. von Herdera ${ }^{40}$. Odrzucili oni francuski klasycyzm ze względu na jego stały, dogmatyczny sens.

37 Por. H.-G. Gadamer, Prawda i metoda, dz. cyt., s. 128.

38 H.-G. Gadamer, Prawda i metoda, dz. cyt., s. 119. „W sposób mniej lub bardziej systematyczny pojęcia takie jak symbol czy alegoria zaczęto odróżniać od siebie dopiero w epoce nowożytnej. Przykładowo wspomniana opozycja estetyczna między alegorią i symbolem została stworzona i rozpropagowana dopiero dwieście lat temu przez takich koryfeuszy romantyzmu, jak Goethe, Schiller, bracia Schleglowie, Schelling, Hegel, Herder, Humboldt, Novalis, Solger, Ast, Tieck i Coleridge. Na gruncie kultury starożytnej natomiast nie może być oczywiście żadnej mowy o przeciwstawieniu «arbitralnej» alegorii «naturalnemu» symbolowi. Od momentu, w którym pojęć takich jak ainigma, symbolon, hypónoia czy allégoría zaczęto używać regularnie w interesującym mnie tutaj kontekście hermeneutycznym, były one stosowane przez Greków w pełni zamiennie w odniesieniu do każdego ukrytego sensu odnośnej wypowiedzi" (M. Domaradzki, Filozofia antyczna wobec problemu interpretacji, dz. cyt., s. 59).

39 „[... symbol i to, co symboliczne, zostają jako znaczące wewnętrznie i istotowo przeciwstawione zewnętrznemu i sztucznemu znaczeniu alegorii" (H.-G. Gadamer, Prawda i metoda, dz. cyt., s. 122).

40 Por. H.-G. Gadamer, Prawda i metoda, dz. cyt., s. 128. 
Decydujący wpływ na podważenie zarówno retorycznego, jak i hermeneutycznego znaczenia alegorii w estetyce miało nowe rozumienie artysty $^{41}$, jego twórczości oraz samego dzieła sztuki. Kant zdefiniował dzieło sztuki ${ }^{42}$ jako nieświadomą twórczość genialnego artysty. Dlatego geniusz, tworząc genialne dzieło, nie może być ograniczony żadnymi dogmatycznymi zasadami alegorii ${ }^{43}$. Także odbiorca, aby zrozumieć dzieło genialne, sam musi być kongenialny, tzn. musi niejako odtwarzać proces twórczy artysty. A zatem geniusz nie posługuje się alegorią w chwili tworzenia dzieła sztuki, a odbiorca nie używa alegorezy do jego zrozumienia. Z punktu widzenia estetyki genialności, gdy występuje alegoria, to mamy do czynienia z rzemiosłem, a nie z dziełem sztuki.

Autor Krytyki władzy sądzenia pojęcie symbolu zastosował do opisu piękna: „[...] piękno jest symbolem tego, co etycznie dobre [...]”44. Według Gadamera „Symbol staje się koincydencją tego, co zmysłowe, i tego, co niezmysłowe, alegoria zaś znaczeniowym odniesieniem tego, co zmysłowe, do tego, co niezmysłowe" ${ }^{\text {45 }}$. Alegoria pozostaje w ścisły sposób związana $\mathrm{z}$ tym, do czego odsyłała i w tym odniesieniu się wyczerpuje. Symbol natomiast jest niewyczerpany w swoim znaczeniu. Jego związek z tym, co symbolizuje, jest wewnętrzny, w przeciwieństwie do alegorii, ponieważ on nie tylko odsyła do znaczenia, ale to znaczenie zawiera także w sobie (chociaż tylko częściowo).

Według Gadamera jednym z najdonioślejszych dokonań Kanta dotyczących dzieła sztuki i związanego z nim pojęcia symbolu było utworzenie pojęcia przedstawienia symbolicznego ${ }^{46}$. Kant w paragrafie 50 Krytyki władzy sądzenia zatytułowanym O pięknie jako symbolu mo-

${ }^{41}$ W klasyce weimarskiej „[...] deprecjacja alegorii była dominującym dążeniem niemieckiej klasyki, zrodzonym z konieczności przez uwolnienie z pęt racjonalizmu i wyodrębnienie się pojęcia geniusza" (H.-G. Gadamer, Prawda i metoda, dz. cyt., s. 129).

42 Por. H.-G. Gadamer, Prawda i metoda, dz. cyt., s. 129.

43 „[...] pojęcie i treść alegorii wiążą się ściśle z dogmatyką; z racjonalizacją tego, co mityczne (tak w epoce greckiego oświecenia), lub z chrześcijańską wykładnią Pisma św. z pozycji jedności doktryny (tak w patrystyce) [...]", (H.-G. Gadamer, Prawda i metoda, dz. cyt., s. 129).

44 I. Kant, Krytyka władzy sądzenia, tłum. J. Gałecki, Warszawa 1986, s. 302.

45 H.-G. Gadamer, Prawda i metoda, dz. cyt., s. 122.

46 Por. H.-G. Gadamer, Prawda i metoda, dz. cyt., s. 123. 
ralności, przeciwstawił przedstawienie unaoczniające pojęcie w schematyzmie przedstawieniu unaoczniającemu w symbolu. W schematyzmie pojęciu uchwyconemu przez intelekt „[...] przydaje się a priori odpowiadającą mu daną naoczną" ${ }^{47}$. Natomiast w przedstawieniu unaoczniającym symbolicznie, pojęciu, które uchwycić może tylko rozum, żadna dana naoczna nie odpowiada adekwatnie. Jeżeli można mówić o pewnym rodzaju adekwatności, to dotyczy on tylko formy refleksji, a nie jej treści. Dla dokładniejszego uchwycenia istoty symbolu Kant dokonał odróżnienia symbolu od symbolu logicznego. Według niego w tym ostatnim logicy dokonali wypaczenia sensu słowa „symbol”, ponieważ użyte przez nich znaki zmysłowe tylko oznaczają pojęcie, a nie zawierają w sobie niczego ${ }^{48}$. Natomiast symbol nie tylko oznacza, lecz przede wszystkim przedstawia. W odróżnieniu od schematyzmów, które przedstawiają bezpośrednio naoczne pojęcia a priori drogą demonstratywną, symbole przedstawiają je pośrednio, w sposób analogiczny. Kant odnalazł w codziennym użyciu języka wiele przestawień symbolicznych, w których „[...] wyraz nie zawiera właściwego schematu dla pojęć, lecz jedynie symbol dla refleksji"49.

Alegoria i jej hermeneutyczna interpretacja stała się czymś mało znaczącym w powstaniu i rozumieniu dzieła sztuki przez Johanna W. von Goethego $^{50}$. Natomiast pojęcie symbolu stało się kluczowym słowem jego estetyki i poglądu na świat ${ }^{51}$. Różnica pomiędzy alegorią a symbolem uwidacznia się w dziele sztuki. Dzięki zastosowaniu alegorii można przeobrazić zjawisko w pojęcie, a pojęcie w obraz. Pojęcie jest dane w obrazie i tym samym jest w nim całkowicie wyrażalne (alegoria służy do unaocznienia zjawiska). W wyniku zastosowania symbolu, w odróżnieniu od alegorii, następuje przemiana zjawiska w ideę, a idei w obraz.

\footnotetext{
47 I. Kant, Krytyka władzy sądzenia, dz. cyt., s. 299.

48 Por. I. Kant, Krytyka władzy sądzenia, dz. cyt., s. 299.

49 I. Kant, Krytyka władzy sądzenia, dz. cyt., s. 301.

50 Por. H.-G. Gadamer, Prawda i metoda, dz. cyt., s. 129.

51 Por. M. Seils, Symbol, [w:] Historisches Wörterbuch der Philosophie, Hrsg. J. Ritter,
} K. Gründer, Basel 1998, s. 726. 
Idea nieskończenie oddziałuje w obrazie i pozostaje zawsze nieosiągalna ${ }^{52}$. Można zatem powiedzieć, że podobnie jak dla Kanta, także dla Goethego różnica pomiędzy alegorią a symbolem jest absolutna.

Gadamer podkreśla, że duże znaczenie w deprecjacji znaczenia alegorii w powstawaniu i rozumieniu dzieła sztuki miało także pojęcie "przeżycia” ${ }^{3}$ występujące w kulturze oświecenia. Odegrało ono ważną rolę w twórczości Goethego, którego poezję uważa się za „spowiedź” życia, artystyczny wyraz przeżyć. Za jego sprawą pojęcie to stało się zasadniczym kryterium wartości dzieła sztuki: „[... [ sztuka wywodzi się z przeżycia i jest jego wyrazem. W sensie pochodnym jednakże pojęcie sztuki przeżycia jest używane także w odniesieniu do takiej sztuki, która jest przeznaczona do estetycznego przeżycia" ${ }^{54}$. Wnikliwe analizy tego pojęcia pojawiły się w filozofii dopiero na przełomie XIX i XX wieku za sprawą Wilhelma Diltheya. Użył on go w tytule artykułu o poezji Goethego: Das Erlebnis und die Dichtung (Przeżycie i poezja). Według Diltheya Goethe, używając pojęcia „przeżycie” w swojej twórczości, przeciwstawił się racjonalizmowi oświecenia i ukazał jego związek z całością życia. Paradoks polega na tym, że Goethe sam stał się zakładnikiem tego kryterium, a mianowicie jego późną poezję związaną z realistycznym duchem epoki uznano za „przeładowaną” alegorią ${ }^{55}$.

\section{Rehabilitacja alegorii dokonana przez Hegla i Vischera}

Gadamer zauważa, że deprecjacja alegorii w pierwszej połowie XIX wieku nie była tendencją powszechną, ponieważ w dalszym ciągu hermeneutyczne zastosowanie alegorii występowało w kulturze starożytnego Wschodu. Także literatura estetyczna, w tym Johanna J. Winckel-

52 Por. różnica pomiędzy ideą a ideatum w myśli Levinasa: E. Lévinas, Całość i nieskończoność. Esej o zewnętrzności, tłum. M. Kowalska, Warszawa 1998, s. 39.

53 Dopiero Dilthey nadał słowu „przeżycie” funkcję pojęciową i od tego czasu stało się modne. W drugiej połowie XIX wieku używała go większość języków europejskich (H.-G. Gadamer, Prawda i metoda, dz. cyt., s. 105).

54 H.-G. Gadamer, Prawda i metoda, dz. cyt., s. 117.

55 Por. H.-G. Gadamer, Prawda i metoda, dz. cyt., s. 129. 
manna, używała pojęć alegorii i symbolu synonimicznie. Friedrich Schlegel w rozważaniach dotyczących piękna (Gespräch über Poeise) uważał, że „wszelkie piękno jest alegorią" ${ }^{26}$.

Przeciwstawienie zimnej, intelektualnej alegorii symbolowi miało swoje źródło w estetyce geniuszu i przeżycia. Powszechne było jednak dążenie dziewiętnastowiecznej humanistyki kultury do uwolnienia sztuki z ograniczeń racjonalizmu (związane to było przede wszystkim z pojęciem geniusza).

W romantyzmie dochodzi do rehabilitacji alegorii w filozofii niemieckiej. Gadamer dostrzega teoretyczną podstawę tej rehabilitacji w filozofii Georga W. F. Hegla i Friedricha Th. Vischera. Według Hegla przede wszystkim to sztuka Wschodu jest symboliczna, ponieważ występuje w niej dysproporcja pomiędzy obrazem a sensem ${ }^{57}$. W Wykładach zestetyki twierdzi, że „Z symbolem spotykamy się głównie w krajach Wschodu, skąd po licznych zmianach przeobrażeniach i zapośredniczeniach prowadzi nas do prawdziwej rzeczywistości ideału jako klasycznej formy sztuki"58. Symbolicznej sztuce Wschodu Hegel przeciwstawił sztukę klasyczną, w której, według niego, nie ma dysproporcji pomiędzy obrazem a sensem. Opiera się ona na bezwzględnie odpowiadającej jedności treści i formy ${ }^{59}$. Hegel odrzucił panujące w klasycyzmie absolutne odróżnienie symbolu od alegorii, a poprzez zawężenie znaczenia pojęcia symbolu zbliżył jego znaczenie do pojęcia alegorii. Jak zaznacza Gadamer, takie dowartościowanie alegorii było czymś rzadkim na tle dziewiętnastowiecznego humanizmu kultury ${ }^{60}$.

Heglowskie rozumienie symbolu podjął i poszerzył Vischer, przez co równocześnie podkreślił znaczenie alegorii. Symbol, według niego, jest wytworem podmiotu. „ "Mroczna symbolika umysłu» obdarza duszą i znaczeniem to, co samo w sobie pozbawione jest duszy (przyrodę

56 H.-G. Gadamer, Prawda i metoda, dz. cyt., s. 128.

57 Por. G. W. F. Hegel, Wykłady o estetyce, tłum. A. Landman, t. 1, Warszawa 1964, s. 499n.

58 G. W. F. Hegel, Wykłady o estetyce, dz. cyt., s. 485.

59 Por. G. W. F. Hegel, Wykłady o estetyce, dz. cyt., s. 482.

60 Por. H.-G. Gadamer, Prawda i metoda, dz. cyt., s. 129. 
lub podpadające pod zmysły zjawisko)"'61. Dowartościowanie alegorii w przypadku Vischera jest przejawem świadomości estetycznej. Dziewiętnastowieczna „religia kultury estetycznej”, związana ze świadomością estetyczną, przeciwstawiała piękno rzeczywistości. „Kiedy mówimy «piękno», brzmi to zawsze tak, jakby chodziło o pewną rzecz, która istnieje. Tymczasem piękno nie istnieje tak, jak istnieje jakaś rzecz" ${ }^{12}$. Nie jest ono rzeczą, lecz subiektywnym aktem podmiotu. To dzięki aktywności podmiotu następuje odniesienie estetyczne podmiotu do przedmiotu. Według Vischera jest to nieświadoma czynność podmiotu i dlatego jest przez niego niezauważalna. Podmiot spontanicznie przenosi swoje stany duchowe na przedmiot i uznaje go za piękny. Pomiędzy pięknem a prawdą istnieje zasadnicza różnica. Prawda jest związana z bytem, natomiast piękno nie dotyczy bytu bezpośrednio, tylko pojawia się w relacji odniesienia podmiotu do tego, co jest (do bytu). Można za Vischerem powiedzieć, że to, co jest piękne, nie jest prawdziwe, a to, co jest prawdziwe, nie jest piękne ${ }^{63}$. Piękno nie jest własnością bytu, lecz stanem emocjonalnym podmiotu, który jest spontanicznie narzucany na byt. Dlatego piękno jako takie (samo w sobie) nie istnieje.

Przypomnijmy, że zgodnie z Kantowską koncepcją geniuszu artysta tworzy niezależnie od wszelkich zasad i pojęć. Vischer zmienił o 180 stopni zależność twórcy - geniusza od pojęć, jakie występują w jego twórczości. Podkreślił mianowicie, że świadomość estetyczna, w odróżnieniu od świadomości mityczno-religijnej, jest świadoma swej wolności. W sposób wolny obdarza wszystko symboliką. Symbol jest tworem wolnego, ludzkiego ducha (ludzkiej świadomości). Pomimo swej wieloznaczności jest on zgodny z pojęciem, które ta świadomość tworzy. Vischer podziela stanowisko Schellinga, że pojęcie symbolu wyraża pełną kompatybilność zjawiska z ideą (pojęciem), natomiast niezgodność charakterystyczna jest dla alegorii i świadomości mityczno-religijnej ${ }^{64}$. Zarówno alegorii, jak

\footnotetext{
61 H.-G. Gadamer, Prawda i metoda, dz. cyt., s. 130.

62 G. Pöltner, Estetyka filozoficzna, tłum. J. Zychowicz, Kraków 2011, s. 178.

63 Por. G. Pöltner, Estetyka filozoficzna, dz. cyt., s. 178.

64 Por. H.-G. Gadamer, Prawda i metoda, dz. cyt., s. 130.
} 
i świadomości mityczno-religijnej nie da się dogmatycznie ująć w pojęcie, tak jak tego chcieli filozofowie oświecenia.

Można powiedzieć, że Hegel dowartościował znaczenie alegorii przez zbliżenie jej do znaczenia symbolu. Vischer natomiast wyprowadził daleko idące konsekwencje z Kantowskiego pojęcia geniuszu i niejako zamienił miejscami symbol z alegorią. W miejsce oświeceniowego pojęcia symbolu wstawił pojęcie alegorii. To znaczenie alegorii, a nie symbolu, jest nacechowane pewną wolnością. Symbol natomiast, odpowiadając pojęciu, staje się czymś dogmatycznym.

\section{Rehabilitacja alegorii dokonana przez Gadamera}

Gadamer sprzeciwia się absolutnemu przeciwstawieniu alegorii symbolowi i jej odrzuceniu w estetyce oświecenia. Pomimo występujących różnic między nimi, mają one także elementy wspólne. Źródeł ich przeciwstawienia doszukuje się on w filozofii starożytnej Grecji ${ }^{65}$. Alegoria związana była ze sferą mówienia, czyli z retoryką. Używano jej wówczas, kiedy należało mówić nie to, co się miało na myśli, lecz to, co było niejako bardziej namacalne, ale w taki sposób, żeby można było zrozumieć to pierwsze. Natomiast symbol nie był tylko figurą retoryczną i hermeneutyczną. W przeciwieństwie do alegorii, jego własny zmysłowy byt miał znaczenie, ponieważ wyrażał logos. Inaczej mówiąc, to dzięki symbolowi logos może się ujawnić i być dla nas dostępny w poznaniu.

Alegoria, jak to zostało już przedstawione, dominowała w literaturze średniowiecznej, przeżywała swój rozkwit od drugiej połowy wieku XVI i w wieku XVII. Gadamer zauważa, że zarówno Winckelmann, jak i cała literatura estetyczna XVIII stulecia, używała pojęć symbolu i alegorii synonimicznie. „[...] oba słowa nazywają coś, czego sens nie polega na zjawiskowości, wyglądzie lub brzmieniu, lecz poza nie wykracza. Wspólność tego znaczenia polega na fakcie, że coś reprezentuje coś innego" ${ }^{\text {"66 }}$. To, co

65 Por. H.-G. Gadamer, Prawda i metoda, dz. cyt., s. 119.

66 H.-G. Gadamer, Prawda i metoda, dz. cyt., s. 119. Symbol, w przeciwieństwie do alegorii, prowadzi od tego, co widzialno-zmysłowe do tego, co niewidzialno-duchowe, czyli od 
jest niezmysłowe (duchowe), dzięki użyciu alegorii lub symbolu stawało się zmysłowo postrzegalne. Dotyczyło to zarówno poezji, jak i sztuk plastycznych. Następną, obok reprezentowania, wspólną cechą alegorii i symbolu było zastosowanie ich przede wszystkim w sferze religijnej. Użycie alegorii i symbolu w sztuce religijnej miało wspólną podstawę w przekonaniu, że poznanie tego, co boskie, może się dokonać przez to, co zmysłowe. Obok powyższych dwóch, Gadamer dostrzega jeszcze trzecią ich wspólną cechę. Czymś wspólnym dla nich jest retoryczno-hermeneutyczne zastosowanie alegorii oraz funkcja anagogiczna symbolu. W retoryce niekiedy stosowniej jest powiedzieć coś nie wprost, niż powiedzieć to bezpośrednio ${ }^{67}$.

Gadamer, pomimo podkreślenia tych podobieństw, nie zaciera różnic pomiędzy symbolem a alegorią. W przypadku symbolu, w przeciwieństwie do alegorii, występuje metafizyczne tło, związane z jego gnostyczną funkcją. Zgodnie z nią „Sfera zmysłowa to nie tylko marność i mrok, lecz emanacja i odblask prawdy"68. Biorąc pod uwagę tę gnostyczną funkcję symbolu, Gadamer twierdzi, że „[... ] symbol nie stanowi dowolnie przyjętego lub ustanowionego znaku, lecz zakłada pewien metafizyczny związek tego, co widziane, $\mathrm{z}$ tym, co niewidziane" ${ }^{\mathrm{s} 9}$. W każdym kulcie religijnym występuje związek niewidzialnego znaczenia $\mathrm{z}$ widzialnym jego przejawem w symbolu. To niejako odpowiada średniowiecznemu rozgraniczeniu pomiędzy prawdą rzeczy a prawdą poznania tej rzeczy. Otóż prawda poznania rzeczy nigdy nie osiąga prawdy samej rzeczy. Wprawdzie i w alegorii występuje ta jedność, ale zewnętrznie, tylko przez wskazanie

znanego ku nieznanemu. Tego, co jest niewidzialne i jako takie nieznane, nie da się w pełni wypowiedzieć, ponieważ związane jest z jego treścią, która jest nieprzebrana. Por. P. Ricoeur, Symbol daje do myślenia, tłum. S. Cichowicz, [w:] P. Ricoeur, Egzystencja i hermeneutyka. Rozprawa o metodzie, opr. S. Cichowicz, Warszawa 1985, s. 62-65.

${ }^{67}$ Podobna sytuacja z niemożnością wypowiedzenia wprost pojawiła się w rozważaniach Pseudo-Dionizego Areopagity (V-VI w.), w których symbol pełnił funkcję anagogiczną w odniesieniu do nadzmysłowego bytu Boga.

68 H.-G. Gadamer, Prawda i metoda, dz. cyt., s. 121. Zdaniem Gadamera bez zrozumienia gnostycznej funkcji symbolu nie można pojąć jego nowoczesnego pojęcia.

69 H.-G. Gadamer, Prawda i metoda, dz. cyt., s. 121. 
na coś innego ${ }^{70}$. Inaczej mówiąc, w przypadku alegorii mamy do czynienia z tożsamością pomiędzy prawdą rzeczy a prawdą jej poznania, czyli prawda epistemologiczna jest tożsama z prawdą ontyczną. Symbol natomiast stanowi wewnętrzną jedność obrazu i znaczenia. W swojej formie należy do świata zmysłowego, a w swej treści odnosi się do świata idei. Pomiędzy tymi dwoma światami występuje napięcie. Z jednej strony mamy do czynienia $\mathrm{z}$ formą symbolu, a $\mathrm{z}$ drugiej z treścią tego (istotą), co jest symbolizowane. Istota tego, co jest symbolizowane, zawiera się częściowo w formie symbolu. W niej jednak się nie wyczerpuje, dlatego odsyła poza siebie do rzeczywistości, którą symbolizuje. W symbolu pojawia się napięcie pomiędzy tym, co jest skończone, a tym, co nieskończone. Występująca dysproporcja pomiędzy formą a istotą symbolu nadaje mu charakter chwiejności. Jeżeli istotę symbolu ujmiemy w formie pojęcia, to wtedy mamy do czynienia z napięciem pomiędzy wyrazem (formą) symbolu a jego treścią, czyli pojęciem.

Zastosowanie alegorii do zmysłowego ukazywania pojęć, w odróżnieniu od symbolu, pozbawione jest metafizycznego tła. Jej znaczenie jest ustanowione konwencjonalnie, w wyniku czego następuje dogmatyczne przyporządkowanie abstrakcyjnym pojęciom ściśle określonych przedstawień. Inna różnica pomiędzy nimi, według Gadamera, polega na tym, że znaczenie symbolu ze względu na jego nieokreśloność jest niewyczerpywalne. Natomiast znaczenie alegorii, w przeciwieństwie do niego, jest ściśle określone i w tym określeniu się wyczerpuje ${ }^{71}$. Ważne w tym względzie jest spostrzeżenie Paula Ricoeura, że „Symbol i alegoria nie stoją w tym samym rzędzie; symbol poprzedza hermeneutykę, alegoria jest już hermeneutyczna. A to dlatego, że symbol oddaje swój sens w sposób przejrzysty, lecz całkiem inaczej, niż to dzieje się przy przekładzie; rzekłbym nawet, iż go przywołuje, "poddaje» (w sensie czasownika greckiego «napomykać», od którego pochodzi słowo «zagadka»), a więc daje go jako zagadkę, a nie oddaje przez przekład. Przeciwstawiłbym, jeśli wolno, dar umożliwiony przez przejrzystość symbolu darowi umożliwionemu przez

70 Por. H.-G. Gadamer, Prawda i metoda, dz. cyt., s. 121.

71 Por. H.-G. Gadamer, Prawda i metoda, dz. cyt., s. 122-123. 
przekład alegorii"72. Dlatego symbol poprzedza hermeneutykę, ponieważ z istoty bytu, który ma być ukazany wynika konieczność jego zastosowania. Przez doświadczenie symboliczne, w przeciwieństwie do alegorii, „[...] to, co jednostkowe, szczególne jest niczym ułamek bytu, że coś, co z nim koresponduje, jest obietnicą uzupełnienia całości i szczęścia"73. Związek pomiędzy symbolem a tym, do czego on odsyła, nie jest ani dowolny, ani sztuczny, jak w przypadku alegorii. Tego, do czego symbol odsyła, nie można powiedzieć ani ukazać w inny sposób, jak tylko za jego pomocą. Inaczej mówiąc, jeżeli nie użyjemy symbolu, to nie mamy dostępu do rzeczywistości, którą on w sobie zawiera i do której odsyła. Symbol, aby mógł być użyty, musi być znany wcześniej, ponieważ w sposób naturalny związany jest z tym, co symbolizuje.

\section{Cel rehabilitacji alegorii dokonanej przez Gadamera}

Powstaje jednak pytanie, w jakim celu Gadamer dokonał rehabilitacji alegorii? Aby odpowiedzieć na to pytanie, należy przeanalizować układ pierwszej części Prawdy i metody, zatytułowanej Kwestia prawdy w doświadczeniu sztuki. Część ta składa się z dwóch rozdziałów: z pierwszego zatytułowanego Przekroczenie wymiaru estetycznego oraz drugiego noszącego tytuł Ontologia dzieła sztuki i jej hermeneutycznego znaczenia. Dla problematyki, która nas interesuje, ważne są: podrozdział drugi (Subiektywizacja estetyki przez Kantowską krytykę) oraz podrozdział trzeci (Restauracja pytania o prawdę sztuki) rozdziału pierwszego. Otóż ostatni punkt podrozdziału drugiego, punkt C nosi nazwę: Granica sztuki przeżycia. Rehabilitacja alegorii. Wskazuje on właściwy cel Gadamerowskiej rehabilitacji alegorii. Punkt C, umieszczony w pierwszym rozdziale Prawdy $i$ metody (Przekroczenie wymiaru estetycznego), stanowi przejście z podrozdziału drugiego (Subiektywizacja estetyki przez Kantowska krytykę) do podrozdziału trzeciego (Restauracja pytania o prawdę sztuki). A zatem

72 P. Ricoeur, Symbol daje do myślenia, dz. cyt., s. 64.

73 H.-G. Gadamer, Aktualność piękna. Sztuka jako gra, symbol i piękno, tłum. K. Krzemieniowa, Warszawa 1993, s. 70. 
z jednej strony Gadamer dąży do przezwyciężenia estetyzacji sztuki i przeżycia estetycznego. Jedno i drugie według niego jest niczym innym, jak „estetycznym cmokierstwem” i „snobizmem estetycznym”. „Idzie się do opery, ponieważ śpiewa Callas, nie zaś dlatego, że wystawiana jest jakaś określona opera"74. A z drugiej strony, chce on wykazać, że dzieło sztuki ukazuje prawdę, ponieważ nie jest ono tylko przedmiotem estetycznej świadomości i estetycznego przeżycia. Jest ono dane w ciągłości tradycji - z niej mówi do doświadczającego go człowieka o prawdzie świata, w którym przyszło mu żyć, jak również o prawdzie, która dotyczy go bezpośrednio.

Rehabilitację alegorii Gadamer wykorzystał do krytyki estetyki filozoficznej i związanej z nią „religii kultury estetycznej”75. Punktem wyjścia estetyki filozoficznej była absolutna wolność symboliczna genialne-

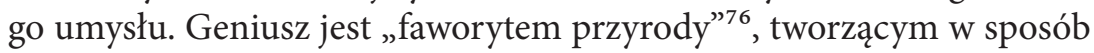
wolny. Dla Gadamerowskiej hermeneutyki filozoficznej absolutna wolność geniusza postulowana przez Kanta i jego następców - Friedricha Schillera i Friedricha W. J. von Schellinga - jest nie do przyjęcia. Jest ona wręcz czymś abstrakcyjnym, ponieważ każda moda artystyczna, każdy impuls twórczy wypływa $z$ tradycji. Genialny twórca może nie zdawać sobie sprawy z tego, że tworzy we wspólnej tradycji, która obowiązuje także i jego. Tradycja ta wyrasta z mitologii i religii, czyli ze świadomości mityczno-religijnej ${ }^{77}$. Biorąc pod uwagę tkwienie każdego $\mathrm{z}$ nas $\mathrm{w}$ tradycji, trzeba zaliczyć główne założenie estetyki przeżycia, jakim jest absolutne przeciwieństwo pomiędzy symbolem a alegorią, do uprzedzeń estetyki $^{7^{8}}$. Przeciwstawienie to jest dogmatem świadomości estetycznej. Drugim jej uprzedzeniem jest absolutne odróżnienie świadomości

$\begin{array}{ll}{ }_{7} & \text { H.-G. Gadamer, Prawda i metoda, dz. cyt., s. } 43 . \\ 75 & \text { H.-G. Gadamer, Prawda i metoda, dz. cyt., s. } 130 . \\ 76 & \text { I. Kant, Krytyka władzy sadzenia, dz. cyt., s. } 249 . \\ 77 & \text { Według Martina Heideggera Dasein jest wrzucony w bycie, według Gadamera czło- }\end{array}$ wiek zastaje siebie wrzuconym w tradycję. Gadamer był uczniem Heideggera. Dla rozumienia bycia według Heideggera najważniejsza jest przyszłość (Sein zum Tode), natomiast dla Gadamera przeszłość, wrzucenie w tradycję. Można zatem powiedzieć, że Gadamer uzupełnia Heideggerowskie rozumienie o przeszłość.

78 Por. H.-G. Gadamer, Prawda i metoda, dz. cyt., s. 131. 
estetycznej od świadomości mitycznej. Sama świadomość estetyczna, według autora Prawdy i metody, zawiera w sobie dogmatyczny moment, jakim jest absolutne odróżnienie symbolu od alegorii, świadomości dzieła sztuki od świadomości mityczno-religijnej. Konsekwencją przyjęcia tego dogmatycznego momentu na gruncie filozofii było uznanie świadomości estetycznej za „punkt Archimedesowy” wszelkiej refleksji estetycznej. Jednak wbrew temu, co ona głosiła, alegoria wraz ze symbolem wyrasta ze wspólnej tradycji chrześcijańsko-mitycznej. A ponieważ filozofowie oświecenia nie dostrzegali, a ściślej mówiąc, nie chcieli dostrzec, tego wspólnego źródła pochodzenia alegorii i symbolu, deprecjonowali alegorię. W związku z uprzedzeniami, które zawiera w sobie świadomość estetyczna, należy według Gadamera, poddać krytyce zarówną ją, jak i związaną z nią koncepcję dzieła sztuki.

Biorąc powyższe zastrzeżenia Gadamera, możemy stwierdzić, że z jednej strony celem rehabilitacji alegorii dokonanej przez niego było odrzucenie świadomości estetycznej i związanej z nią koncepcji sztuki, jako czegoś abstrakcyjnego, nieodpowiadającego rzeczywistemu stanowi rzeczy. Natomiast z drugiej strony - ukazanie prawdy związanej z dziełem sztuki. Niejako potwierdzeniem naszych przypuszczeń jest określenie przez niego celu badań we Wprowadzeniu do Prawdy i metody: „[...] poniższe badania wychodzą od krytyki świadomości estetycznej, aby doświadczenia prawdy, jaką nas obdarza dzieło sztuki, bronić przed teorią estetyczną, zawężoną przez pojęcie prawdy naukowej. Nie poprzestają one jednak na uprawomocnieniu prawdy sztuki. Usiłują raczej rozwinąć na tej podstawie pojęcie poznania i prawdy odpowiadające całemu naszemu doświadczeniu hermeneutycznemu"79.

Gadamer, w oparciu o rehabilitację alegorii, ale także przez dowartościowanie przesądu, autorytetu i tradycji, podejmuje w Prawdzie i meto$d z i e$ rewizję podstawowych pojęć estetycznych: przeżycia estetycznego, estetycznego odróżnienia oraz pojęcia geniuszu. Odrzucenie przez niego świadomości estetycznej jako pojęcia abstrakcyjnego doprowadziło do zanegowania rozumienia dzieła sztuki jako wytworu geniusza. Ukazało 
ono także możliwość powrotu do rozumienia dzieła sztuki w jego funkcji życiowej, religijnej lub świeckiej, zrozumiałej dla każdego człowieka ${ }^{80}$.

Pozostaje nam jeszcze odpowiedzieć na pytanie: jakie Gadamer wyciąga merytoryczne konsekwencje z deprecjacji alegorii? Jego zdaniem, „[...] przeciwstawienie pojęcia «organicznie» wyrosłego symbolu zimnej, intelektualnej alegorii traci moc, gdy dostrzec związek tego przeciwieństwa z estetyką geniuszu i przeżycia" ${ }^{\prime 1}$. Autor Prawdy i metody dostrzega zarówno praktyczną, jak i teoretyczną podstawę rehabilitacji alegorii. Jeśli chodzi o praktyczną podstawę rehabilitację alegorii to, według niego, można ją dostrzec $\mathrm{w}$ zainteresowaniu $\mathrm{w}$ drugiej połowie $\mathrm{XX}$ wieku poezją baroku oraz dziełami sztuki pochodzącymi z tego okresu ${ }^{82}$. Innym przejawem zainteresowania alegorią są rozwijane współcześnie badania dotyczące dziejów sztuki. Paradoksalnie Gadamer upatruje teoretyczną podstawę jej rehabilitacji w samej symbolicznej działalności umysłu, która była w XIX wieku odpowiedzialna za jej deprecjację. Według niego filozofowie - estetycy, którzy powoływali się na nią, byli w błędzie, twierdząc, że to sama czysta działalność umysłu tworzy symbole, które następnie narzuca na byt. Każda działalność umysłu jest związana z tradycją i z niej wypływa, a zatem również estetyczno-symboliczna świadomość jest związana ze świadomością mityczno-alegoryczną, ponieważ obie wypływają z tradycji. Czysta świadomość estetyczna jest abstrakcją, a dzieła sztuki nie są tylko i wyłącznie jej wytworem, jak to twierdzili estetycy w XIX wieku.

\section{Zakończenie}

Powstanie w XVIII wieku estetyki i jej rozwój w XIX wieku doprowadziły do zrodzenia się świadomości estetycznej. Natomiast napięcie, które pojawiło się pomiędzy oświeceniem a romantyzmem, doprowadziło do odkrycia i dowartościowania świadomości mitycznej. Ze 
świadomością estetyczną złączono wieloznaczną nieokreśloność symbolu, natomiast świadomości mityczno-religijnej przyporządkowano alegorię. Następstwem przeciwstawienia sobie obu tych świadomości było absolutne przeciwstawienie symbolu i alegorii. „Ponieważ świadomość estetyczna - w przeciwieństwie do mityczno-religijnej - ma świadomość swej wolności, to «wolna» jest również symbolika, którą świadomość ta wszystko obdarza" ${ }^{\text {"3 }}$. W związku z tym wydaje się, że symbol jest tworem ludzkiego ducha i jako figura retoryczna jest ustanowiony przez ludzką świadomość. Podobnie jak w przypadku alegorii jego znaczenie hermeneutyczne musi być następstwem rozpoznania jego znaczenia retorycznego. Jednak tej zależności pomiędzy ludzką świadomością a symbolem Gadamer nie zauważa.

Gadamer źródeł deprecjacji alegorii w oświeceniu doszukuje się w estetyzacji sztuki dokonanej przez Kanta oraz w teorii sztuki Goethego. Wspólnym mianownikiem ich poglądów czyni absolutne przeciwstawienie alegorii symbolowi. Alegoria była rozumiana przez nich jako przedstawienie konwencjonalne, ściśle określone racjonalnie, związane z tradycją i świadomością mityczno-religijną. Natomiast symbol wyrażał swobodną twórczość geniusza, wolną od wszelkiej tradycji, związaną ze świadomością estetyczną. Nowożytna estetyka, zdaniem autora Prawdy $i$ metody, jest wierna temu oświeceniowemu, absolutnemu przeciwstawieniu alegorii symbolowi.

Według Gadamera świadomość estetyczna jest poznawczą odpowiedzią odbiorcy dzieła sztuki na swobodną działalność symboliczną artysty. Dzieło sztuki, będąc tworem geniusza, jest czymś niepowtarzalnym, jedynym w swoim rodzaju. Geniusz tworzy pod wpływem natchnienia, niezależnie od jakichkolwiek norm i zasad. To on stwarza nowe zasady i normy w trakcie tworzenia. Jego dzieło jest dziełem symbolicznym, dlatego nie można go wytłumaczyć na podstawie zastanych tradycyjnych zasad i norm. Nie można także poznawczo wyczerpać jego treści. Żeby zrozumieć dzieło geniusza, trzeba kongenialności jego odbiorcy. Arcydzieło zawsze wykracza poza określone normy i tworzy własne zasady, które 
można odkryć dopiero po jego zaistnieniu. Zasady, według jakich ono powstało, są zawarte w nim samym. Nie można dzieła sztuki oceniać podług zasad już istniejących, tradycyjnych, ponieważ gdyby według nich powstało, nie byłoby dziełem genialnym.

Świadomość mityczno-religijna, z punktu widzenia oświeceniowej świadomości estetycznej, jest ściśle określona przez prawa, reguły i normy. Artysta, który w swojej twórczości wykorzystuje alegorię, nie może wytworzyć dzieła sztuki. Może on wprawdzie namalować obraz czy napisać określony tekst, jednakże nigdy nie będą one dziełami sztuki. Warunkiem koniecznym, aby artysta stworzył dzieło sztuki, jest jego wolność od wszelkich zastanych kanonów, praw i reguł tworzenia, które przekazuje tradycja. Alegoria takiej wolności nie zapewnia, ponieważ jej reguły są ściśle określone pojęciowo przez tradycję religijno-mityczną. Z jej pomocą można ukazać prawdy historyczne, zasady obyczajowe, wzbudzić określone uczucia religijno-patriotyczne, ale nie można ukazać piękna. Piękno jest zarezerwowane dla wolnej, symbolicznej twórczości geniusza. Zdaniem Gadamera w estetyce od czasów oświecenia występuje dychotomia. Z jednej strony występuje symboliczna twórczość geniusza, który tworzy dzieło sztuki i przedstawia piękno. Stanowi ono przedmiot świadomości estetycznej. Tylko ten jest w stanie je kontemplować, kto na genialność dzieła odpowie kongenialnością poznania. Ceną, jaką należy zapłacić za ten przywilej, jest oderwanie się od wszelkich związków praktyczno-życiowych, ale także rezygnacja z prawdy. Domeną dzieła sztuki jest tylko i wyłącznie piękno. A z drugiej strony, z perspektywy geniusza, mamy do czynienia ze świadomością mityczno-religijną, w której obowiązują pewne zasady, normy, kanony tworzenia i postępowania, ale w której nie ma żadnej możliwości, aby powstało dzieło sztuki i aby doświadczyć piękna.

Gadamer dostrzega początki rehabilitacji alegorii już w epoce romantyzmu. Najpierw Hegel odrzucił panujące w klasycyzmie absolutne odróżnienie symbolu od alegorii, a następnie Vischer wykazał, biorąc pod uwagę Kantowską estetykę geniuszu, że to alegoria, a nie symbol, daje artyście wolność tworzenia.

Gadamer sprzeciwia się absolutnemu przeciwstawieniu alegorii symbolowi, ponieważ pomiędzy nimi obok różnic występują podobieństwa. 
Zarówno alegoria, jak i symbol reprezentują sobą coś innego. Z reprezentacją związana jest ich druga wspólna funkcja polegająca na ich obecności w sferze religijnej. Dzięki ich zastosowaniu to, co duchowe, może być poznane przez to, co zmysłowe. Trzecią ich wspólną cechą jest ich retoryczno-hermeneutyczne zastosowanie.

Natomiast podstawowa różnica między alegorią a symbolem polega na obecności w tym ostatnim metafizycznego tła. Biorąc je pod uwagę, można powiedzieć, że w symbolu występuje wewnętrzny związek pomiędzy tym, co widzialne, a tym, co niewidzialne. Jego znaczenie ze względu na jego nieokreśloność jest niewyczerpywalne. Alegoria, w której brak tego tła, swoje znaczenie posiada dzięki ustanowieniu konwencjonalne$\mathrm{mu}$. Jest ono ściśle określone i w tym określeniu się wyczerpuje.

Gadamer krytykuje estetykę filozoficzną i neguje związaną z nią absolutną wolność symboliczną genialnego umysłu. Rozumienie każdego człowieka, w tym także artysty, dokonuje się w określonym horyzoncie tradycji religijno-mitycznej. Dlatego należy uznać podstawowe założenia estetyki przeżycia za uprzedzenia. Przede wszystkim należy rozstać się z dogmatem świadomości estetycznej, jakim jest przeciwstawienie absolutne symbolu alegorii. Jak również z absolutnym odróżnieniem świadomości estetycznej od świadomości mitycznej, ponieważ w rozumieniu mamy do czynienia ze scaleniem ich horyzontów.

Celem rehabilitacji alegorii było odrzucenie świadomości estetycznej i związanej z nią koncepcji dzieła sztuki jako tworu geniusza. Dzieło sztuki nie jest tylko doświadczeniem piękna, ale przede wszystkim ukazuje poznającemu go prawdę o jego życiu i prawdę o otaczającej go rzeczywistości. Gadamer dzięki rehabilitacji alegorii wskazał na podstawowe funkcje życiowe, religijne i świeckie dzieła sztuki, zrozumiałego dla każdego człowieka.

\section{Bibliografia}

Św. Augustyn, O nauce chrześcijańskiej, tłum. J. Sulowski, Warszawa 1989.

Św. Augustyn, O Trójcy świętej, tłum. M. Stokowska, Poznań-Warszawa- Lublin 1963. 
Grondin J., Wprowadzenie do hermeneutyki filozoficznej, tłum. L. Łysień, Kraków 2007. Léon-Dufour X. SJ, Słownik Nowego Testamentu, tłum. bp K. Romaniuk, Poznań 1986.

Domaradzki M., Filozofia antyczna wobec problemu interpretacji. Rozwój alegorezy od przedsokratyków do Arystotelesa, Poznań 2013.

Gadamer H.-G., Aktualność piękna. Sztuka jako gra, symbol i piękno, tłum. K. Krzemieniowa, Warszawa 1993.

Gadamer H.-G., Klassische und philosophische Hermeneutik, [w:] H.-G. Gadamer, Gesammelte Werke 2. Hermeneutik II, Tübingen 1993, s. 92-117.

Gadamer H.-G., Mythos und Logos, [w:] H.-G. Gadamer, Gesammelte Werke 8. Ästhetik und Poetik I, Tübingen 1993, s. 170-173.

Gadamer H.-G., Prawda i metoda. Zarys hermeneutyki filozoficznej, tłum. B. Baran, Kraków 2004.

Grelot P., Typ, [w:] Słownik teologii biblijnej, red. X. Leon-Dufour, tłum. bp K. Romaniuk, Poznań-Warszawa 1985, s. 992-997.

Hegel G. W. F., Wykłady o estetyce, tłum. A. Landman, t. 1, Warszawa 1964.

Kant I., Krytyka władzy sq̨dzenia, tłum. J. Gałecki, Warszawa 1986.

Lévinas E., Całość i nieskończoność. Esej o zewnętrzności, tłum. M. Kowalska, Warszawa 1998.

Pöltner G., Estetyka filozoficzna, tłum. J. Zychowicz, Kraków 2011.

Reale G., Historia filozofii starożytnej, tłum. E. I. Zieliński, t. 5, Lublin 2002.

Ricoeur P., „Symbol daje do myślenia”, tłum. S. Cichowicz, [w:] P. Ricoeur, Egzystencja i hermeneutyka. Rozprawa o metodzie, opr. S. Cichowicz, Warszawa 1985, s. 58-75.

Ripa C., Ikonologia, tłum. I. Kania, Kraków 1998.

Sarnowska-Temeriusz E., Alegoria, [w:] Słownik literatury staropolskiej, red. T. Michałowska, Wrocław-Warszawa-Kraków 1998, s. 20-26.

Seils M., Symbol, [w:] Historisches Wörterbuch der Philosophie, Hrsg. J. Ritter, K. Gründer, t. 9, Basel 1998, s. 725-729.

Sołtysiak M., Symbol hermeneutyczny a symboliczność dzieła sztuki według Hansa-Georga Gadamera, „Logos i Ethos” 2014 nr 2 (37), s. 21-46.

Wojciechowska K., Alegoria, [w:] Religia, red. T. Gadacz, B. Milerski, t. 1, Warszawa 2001, s. 138-139.

Wojciechowska K., Alegoryczna interpretacja Biblii, alegoreza, [w:] Religia, red. T. Gadacz, B. Milerski, t. 1, Warszawa 2001, s. 139-141.

Tatarkiewicz W., Historia estetyki. Estetyka nowożytna, t. 3, Warszawa 1991. 